\title{
Adsorption of benzalkonium chlorides onto powdered activated carbon: mechanisms and detoxification
}

\author{
Tae-Kyoung Kim ${ }^{1,4}$, Woo-Seok Choe ${ }^{2}$, Taeyeon Kim², Seon-Ha Chae ${ }^{3}$, Yu Sik Hwang ${ }^{4}$, Kyung-Duk Zoh ${ }^{2+}$ \\ ${ }^{1}$ Department of Civil and Environmental Engineering, University of California, Berkeley, California 94720, United States \\ ${ }^{2}$ Department of Environmental Health Sciences, School of Public Health, Seoul National University, Seoul 08826, Republic of Korea \\ ${ }^{3}$ Korea Water Resources Corporation, K-water Institute, Deajeon 34350, Republic of Korea \\ ${ }^{4}$ Environmental Fate and Exposure Research Group, Korea Institute of Toxicology, Jinju 52834, Republic of Korea
}

\begin{abstract}
Because disinfectants have been essential during the COVID-19 pandemic, the global demand for benzalkonium chlorides (BACs) has significantly increased. BACs can inactivate coronaviruses, but are known as toxic. In this study, we investigated the adsorption mechanisms of $\mathrm{BAC}_{12}$, $\mathrm{BAC}_{14}$ and $\mathrm{BAC}_{16}$ in water using powdered activated carbon (PAC). The effects of the reaction time, $\mathrm{pH}$, and temperature on the adsorption kinetics of BACs were examined. The adsorption reaction followed pseudo-second-order kinetics, and better fitted to the Langmuir isotherm than the Freundlich isotherm. The best adsorption of BACs was achieved at neutral $\mathrm{pH}$ conditions. Thermodynamic analysis revealed that adsorption of BACs onto PAC is a spontaneous and endothermic process. Competitive adsorption experiments revealed that BACs with longer alkyl chains were adsorbed more effectively onto PAC than shorter alkyl chain BACs, implying that, while the electrostatic interaction is an important adsorption mechanism for $\mathrm{BAC}_{12}$, van der Waals interaction plays a more important role during the adsorption of $\mathrm{BAC}_{14}$ and $\mathrm{BAC}_{16}$. Finally, we observed the partial detoxification $(69 \%)$ BAC in adsorption treated water with PAC using a Microtox test.
\end{abstract}

Keywords: Adsorption, Benzalkonium chlorides, Langmuir isotherm, Microtox test, Powdered activated carbon

\section{Introduction}

Quaternary ammonium compounds (QACs) have been widely used as cationic surfactants for fabricating industrial products, such as antimicrobial soap, disinfectants, detergents, fabric softeners, preservatives, and pest control products since 1935 [1]. Among the 430 disinfectants listed by the US EPA, which included chlorine, $\mathrm{H}_{2} \mathrm{O}_{2}$, and QACs, QACs accounted for $50 \%$ of the reported disinfectants to date [2]. In addition, QACs have been recently recognized as capable of inactivating corona viruses.

Benzalkonium chlorides (BACs) are well-known QACs. BACs account for $95 \%$ of all QAC-based disinfectants reported to date [2]. BACs consist of a positively charged nitrogen atom linked to a long alkyl chain (typically 12-18 carbon atoms in length) on one side and a benzyl group on the other [3]. Among the BACs reported to date, benzyl dimethyl dodecyl ammonium chloride $\left(\mathrm{BAC}_{12}\right)$, benzyl dimethyl tetradecyl ammonium chloride $\left(\mathrm{BAC}_{14}\right)$, and benzyl dimethyl hexadecyl ammonium chloride

This is an Open Access article distributed under the terms of the Creative Commons Attribution Non-Commercial License (http://creativecommons.org/licenses/by-nc/3.0/) which permits unrestricted non-commercial use, distribution, and reproduction in any medium, provided the original work is properly cited.

Copyright (C) 2022 Korean Society of Environmental Engineers
$\left(\mathrm{BAC}_{16}\right)$ have been widely used because of their high bioavailability [4]. Also, BACs replaced well-known alternative disinfectants such as triclosan, triclocarban, benzethonium chloride, and chloroxylenol [5, 6].

Recent reports have indicated that the demand for BACs will increase during the severe acute respiratory syndrome-Coronavirus-2 (SARS-CoV-2) pandemic [2] because BACs effectively inactivate the SARS-CoV-2 virus [7]. Therefore, high concentrations of BACs are using for laundry, sterilization, and hospital cleaning to prevent infections these days [8, 9]. The market report published before the SARS-CoV-2 pandemic indicated that the continuous growth rate of BACs is expected to reach $8.7 \%$ by 2025 [10]. However, BACs are known for their high toxicity values for the aquatic organisms. The $\mathrm{EC}_{50}$ immobilization values of BAC for Daphnia magna was $16 \mu \mathrm{g} \mathrm{L}^{-1}[11]$.

Previous studies reported that BACs can be frequently detected in the effluents of the wastewater treatment plants (WWTPs). The concentration of BACs in hospital wastewater effluents can range

Received October 06, 2021 Accepted December 01, 2021

${ }^{\dagger}$ Corresponding author

E-mail: zohkd@snu.ac.kr

Tel: +822-880-2737 Fax: +822-762-2888

ORCID: 0000-0002-0995-1254 
up to between 0.05 and $6.03 \mathrm{mg} \mathrm{L}^{-1}$ [12]. BACs in the influents and effluents of WWTPs also have been detected in the range of 25-300 and 2.1-4.1 $\mu \mathrm{g} \mathrm{L} \mathrm{L}^{-1}$ respectively [13, 14]. As BACs usage has increased after the pandemic, it is predicted that the detection levels of BACs will be significantly increasing.

Municipal WWTPs can degrade up to $97 \%$ of BACs during the activated sludge process and reduce the content of BACs to parts per billion levels [13]. However, owing to their high toxicity, BACs are known to inhibit biological treatment processes at high concentrations such as parts per million levels (3 to 40 $\mathrm{mg} \mathrm{L}^{-1}$ ) $[15,16]$. BACs are more toxic than the antimicrobials they replaced. A recent report has indicated that BACs exhibited acute lethal toxicity even at environmentally relevant levels (hundreds of $\mu \mathrm{g} \mathrm{L}^{-1}$ ) [17]. In addition, the predicted non-effective concentration of BACs has been reported to be $0.0014 \mu \mathrm{g} \mathrm{L}^{-1}$ [18]. Consequently, BACs pose high environmental risks even at low concentrations.

As chemical treatment options, advanced oxidation processes (AOPs) have been applied to treat BACs before the discharge of BACs containing wastewaters. Among AOPs, $\mathrm{H}_{2} \mathrm{O}_{2} / \mathrm{Fe}^{2+}, \mathrm{UV} / \mathrm{Cl}_{2}$, $\mathrm{O}_{3} / \mathrm{H}_{2} \mathrm{O}_{2}$, and $\mathrm{O}_{3} / \mathrm{Cl}_{2}$ reactions have been studied [19-22]. However, the specific facilities and additional oxidants are needed for the implementation of these AOPs in the fields. Instead, another option as a physical removal process, the adsorption process can be easily implemented and does not require specific facilities. Previous reports have described the adsorptive removal of environmentally relevant level BACs using municipal sludge and natural clays [23-26]. However, to our best knowledge, there are no studies on the adsorption removal containing BACs, especially BAC mixtures $\left(\mathrm{BAC}_{12}, \mathrm{BAC}_{14}\right.$, and $\left.\mathrm{BAC}_{16}\right)$ using commercially available adsorbents such as powered activate carbon (PAC).

In this study, we investigated the adsorption mechanisms of the most widely used BACs, namely $\mathrm{BAC}_{12}, \mathrm{BAC}_{14}$, and $\mathrm{BAC}_{16}$ using commercially available PAC to tackle the increasing use of BACs during the COVID-19 pandemic. The effects of time, $\mathrm{pH}$, and temperature on the adsorption kinetics of each BAC were examined along with the kinetic isotherm and thermodynamic analysis. Also, the competitive adsorption kinetics of binary and ternary BAC mixtures $\left(\mathrm{BAC}_{12}, \mathrm{BAC}_{14}\right.$, and $\left.\mathrm{BAC}_{16}\right)$ were performed to compare the relative removal of each BAC by PAC. In addition, Microtox toxicity test was conducted to ensure that BAC detoxification is achieved after the adsorption process.

\section{Materials and Methods}

\subsection{Materials}

$\mathrm{BAC}_{12}$ (benzyl dimethyl dodecyl ammonium chloride), $\mathrm{BAC}_{14}$ (benzyl dimethyl tetradecyl ammonium chloride), $\mathrm{BAC}_{16}$ (benzyl dimethyl hexadecyl ammonium chloride), sodium phosphate monobasic, sodium phosphate dibasic, phosphoric acid $\left(\mathrm{H}_{3} \mathrm{PO}_{4}\right)$, ammonia solution, ammonium chloride, and acetic acid were purchased from Sigma-Aldrich (St. Louis, MO, USA). Subscript numbers in BAC represent the chain length of each BAC. All chemicals were of analytical grade and were used as received without further purification. Synthetic wastewater including buffer solutes and BACs was prepared using deionized water. Coconut shell-based PAC was provided by SK carbon (Yangsan, Korea). PAC was applied to adsorption experiments without further treatment. The physicochemical properties of BACs are summarized in Table S1 in the Supporting Information.

\subsection{Adsorption Experiment}

PAC was washed with distilled water three times to remove any impurities prior to the adsorption experiment. Thereafter, the washed PAC was filtered using a $0.45 \mu \mathrm{m}$ membrane filter (ADVANTEC, Tokyo, Japan), followed by drying in an oven at $80^{\circ} \mathrm{C}$ for $12 \mathrm{~h}$.

To examine the adsorption kinetics and isotherm, we conducted the adsorption experiment in a jar tester. $0.45 \mathrm{~g}$ of freshly prepared PAC was added to $400 \mathrm{~mL}$ of deionized water containing BACs in $0.01 \mathrm{M}$ phosphate solution. To obtain accurate kinetic data and experimental tractability, we used the concentration of BACs in the range between 200 and $450 \mathrm{mg} \mathrm{L}^{-1}$, which is below the critical micelle concentration (CMC) of $\operatorname{BAC}\left(1,320 \mathrm{mg} \mathrm{L}^{-1}\right)$ [27]. It is because the concentration of BAC solution for laundry and sterilization $(0.7-7 \%)$ is much higher than CMC [28, 29]. The $\mathrm{pH}$ was fixed to 7 using a $0.01 \mathrm{M}$ phosphate buffer and the temperature was fixed to $25^{\circ} \mathrm{C}$. To investigate the effect of $\mathrm{pH}$, the $\mathrm{pH}$ of the solution was adjusted in the range of 4 to 8.5 using $0.01 \mathrm{M}$ phosphate buffer and $0.01 \mathrm{M}$ ammonia buffer solutions. The agitating speed was set at $50 \mathrm{rpm}$, and the temperature was remained at 4,25 , and $35^{\circ} \mathrm{C}$ to understand the mechanisms of BACs onto PAC by obtaining the thermodynamic parameters. The relative humidity during the experiments was maintained $50 \pm 5 \%$ by using the isothermal-isohumidity air conditioning system.

To examine the competitive adsorption of BACs, we conducted experiments using three binary BAC combinations $\left(\mathrm{BAC}_{12}\right.$ \& $\mathrm{BAC}_{14}$, $\mathrm{BAC}_{12} \& \mathrm{BAC}_{16}$, and $\mathrm{BAC}_{14} \& \mathrm{BAC}_{16}$ ) and a ternary BAC mixture $\left(\mathrm{BAC}_{12} \& \mathrm{BAC}_{14} \& \mathrm{BAC}_{16}\right)$. The concentration of each $\mathrm{BAC}$ in the binary and ternary mixtures was set at $100 \mathrm{mg} \mathrm{L}^{-1}$; therefore, the total concentration of BACs in the binary and ternary mixtures was 200 and $300 \mathrm{mg} \mathrm{L}^{-1}$, respectively.

\subsection{Analysis}

All samples were filtered prior to analysis to remove PAC using a $1 \mathrm{~mL}$ syringe (Korea vaccine, Ansan, Republic of Korea) and a $0.2 \mu \mathrm{m}$ membrane filter (ADVANTEC, Tokyo, Japan).

The concentration of BACs was determined using a high-performance liquid chromatography (HPLC) system equipped with a UV detector (Ultimate ${ }^{\mathrm{TM}} 300$ 0, Dionex, Sunnyvale, CA, USA). The UV wavelength was set at $262 \mathrm{~nm}$. A Luna ${ }^{\circledR} 5 \mu \mathrm{m}$ C18 column (Phenomenex, $150 \mathrm{~mm} 4.6 \mathrm{~mm}, 100 \AA$ ) connected to a guard column (Phenomenex, $4 \mathrm{~mm} 3.0 \mathrm{~mm}$ ) was used to separate the BACs. A mixture of acetonitrile and $0.2 \mathrm{M}$ ammonium acetate ( $\mathrm{pH}=5$, adjusted with $\mathrm{H}_{3} \mathrm{PO}_{4}$ ) was used as the mobile phase $(80: 20(\mathrm{~V} / \mathrm{V}) \%)$. We set the flow rate at $1.0 \mathrm{~mL} \mathrm{~min}^{-1}$ in isocratic mode, and the injection volume was $100 \mu \mathrm{L}$. The total HPLC runtime was 18 min. The limits of detection of $\mathrm{BAC}_{12}, \mathrm{BAC}_{14}$, and $\mathrm{BAC}_{16}$ were $0.26,0.38$, and $0.42 \mathrm{mg} \mathrm{L}^{-1}$, respectively. 
A surface area analyzer (ASAP 2420, Micrometrics, Norcross, GA, USA) and the Brunauer-Emmett-Teller method were used to determine the surface area of PAC. The point of zero charge $\left(\mathrm{pH}_{\mathrm{pzc}}\right)$ of PAC was evaluated using the $\mathrm{pH}$ drift method (Faria et al., 2004). The zeta potential of PAC was examined using a zeta analyzer at pH 7 (ELSZ-1000, Otsuka Electronics, Osaka, Japan). The physicochemical properties of PAC are summarized in Table S2. The surface area, pore-volume, and pore size of PAC were $945 \mathrm{~m}^{2} \mathrm{~g}^{-1}, 0.52 \mathrm{~cm}^{3} \mathrm{~g}^{-1}$, and $21.9 \AA\left(21.9 \times 10^{-10} \mathrm{~m}\right)$, respectively. The zeta potential and $\mathrm{pH}_{\mathrm{pzc}}$ of PAC were $-26.49 \mathrm{mV}$ at $\mathrm{pH} 7$ and 6.48, respectively. This result indicates that the surface charge of $\mathrm{PAC}$ is negative at $\mathrm{pH}$ higher than 6.48.

\subsection{Adsorption Isotherms}

The Langmuir model represents the equilibrium distribution of ions between solid and liquid phases [30]. The Langmuir model is based on several assumptions; the adsorbed molecules do not interfere with each other, adsorption occurs via the same mechanism, and molecules adsorb onto the adsorbent outer surface as a homogeneous layer [25]. The equations for the Langmuir model can be expressed in Eq. (1) and (2);

$$
\begin{gathered}
q_{e}=q_{\max } \frac{K_{L} C_{e}}{1+K_{L} C_{e}} \\
\frac{C_{e}}{q_{e}}=\frac{1}{q_{\max }} \times \frac{1}{K_{L}}+\frac{1}{q_{\max }} \times C_{e},
\end{gathered}
$$

where $K_{\mathrm{L}}\left(\mathrm{L} \mathrm{mg}^{-1}\right)$ is the Langmuir constant related to the adsorption capacity $\left(\mathrm{mg} \mathrm{g}^{-1}\right)$ and $q_{\max }\left(\mathrm{mg} \mathrm{g}^{-1}\right)$ is the maximum adsorption capacity. $K_{L}$ and $q_{\max }$ can be obtained from the slope and y-intercept, respectively, of the linear regression of $C_{e}$ vs. $C_{e} / q_{e}$.

The Freundlich isotherm model is used to describe adsorption on heterogeneous surfaces. The Freundlich model assumes that multilayer adsorption occurs rather than single-layer adsorption [31]. Heterogeneous adsorption occurs when the adsorbate enters the adsorbent and is subsequently adsorbed. Theoretically, the adsorbed amount increases continuously; therefore, an adsorption equilibrium cannot be attained [32]. The Freundlich model equation can be expressed as Eq. (3) and (4);

$$
\begin{gathered}
q_{e}=K_{F} \times C_{e}^{1 / n} \\
\log \left(q_{e}\right)=\log \left(K_{F}\right)+\frac{1}{n} \log \left(C_{e}\right)
\end{gathered}
$$

where $K_{F}\left((\mathrm{mg} / \mathrm{g}) /(\mathrm{mg} / \mathrm{L})^{1 / n}\right)$ is the Freundlich constant and $n$ is the adsorption intensity. $K_{F}$ and $n$ can be obtained from the slope and y-intercept, respectively, of the linear regression of $\ln \left(C_{e}\right)$ vs. $\ln \left(q_{e}\right)$.

\subsection{Acute Toxicity Test}

The acute toxicity of the BACs was examined using a standard Microtox ${ }^{\circledR}$ bioassay by determining the changes in the luminescence of Vibrio fischeri. The samples were adjusted using an osmotic adjusting solution $(2 \% \mathrm{NaCl})$ to maintain an appropriate osmotic pressure for the luminescent bacteria. The $\mathrm{pH}$ of each sample was maintained at pH 7 using $10 \mathrm{mM}$ phosphate buffer. The initial luminescence was determined using $0.5 \mathrm{~mL}$ of diluent and 10 $\mu \mathrm{L}$ of a solution containing $V$. fischeri. We measured the change in the luminescence after injecting $0.5 \mathrm{~mL}$ of sample into the diluent containing $V$. fischeri and waiting for $5 \mathrm{~min}$.

\section{Results and Discussion}

\subsection{Adsorption Kinetics}

The adsorption experimental results showed that, within the first 10 min of reaction, approximately $80 \%$ of the BACs in the aqueous solution was removed by PAC, and were almost completely removed within 120 min (Fig. 1). This result indicates that PAC is suitable for BACs removal in the aspect of time efficiency. In fact, agricultural soils only achieved $20-50 \%$ and $30-80 \%$ removal of $\mathrm{BAC}_{12}$ and $\mathrm{BAC}_{14}$ in $24 \mathrm{~h}$, and biodegradation treatment took 19 days to eliminate $100 \%$ of BACs [33].

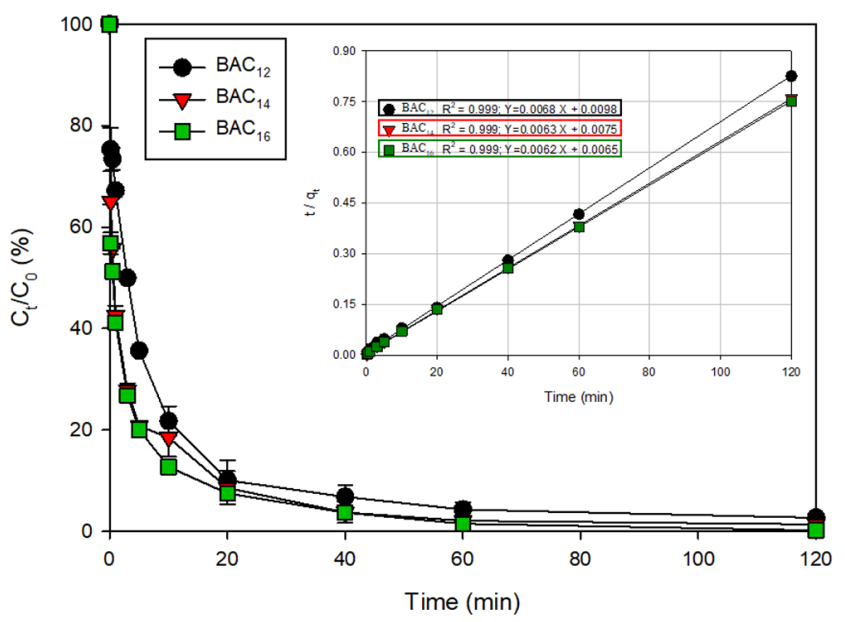

Fig. 1. Adsorption removal kinetics of benzalkonium chlorides (BACs) using powdered activated carbon $\left([\mathrm{BAC}]=200 \mathrm{mg} \mathrm{L}^{-1}, \mathrm{pH}\right.$ $=7.0$, temperature $=25^{\circ} \mathrm{C},[\mathrm{PAC}]=1.2 \mathrm{~g} \mathrm{~L}^{-1}$ ).

The adsorption kinetic results were fitted using two kinetic models [34, 35]. The pseudo-first order (PFO) and pseudo-second order (PSO) kinetic models can be applied in the adsorption kinetics as shown in Eq. (5) and (6), respectively;

$$
\begin{gathered}
\ln \left(q_{e}-q_{t}\right)=\ln \left(q_{e}\right)-k_{1} t \\
\frac{\mathrm{t}}{q_{t}}=\frac{1}{k_{2} q_{e}^{2}}+\frac{t}{q_{e}},
\end{gathered}
$$

where $t$ (min) is the time, $q_{t}\left(\mathrm{mg} \mathrm{g}^{-1}\right)$ is the amount of BAC adsorbed at time $t$, which can be measured during the kinetic experiment, and $k_{1}\left(\mathrm{~min}^{-1}\right)$ and $k_{2}\left(\mathrm{~g} \mathrm{mg}^{-1} \mathrm{~min}^{-1}\right)$ are the rate constants for the PFO and PSO kinetic models, respectively. The adsorption kinetics results were better fitted to the PSO kinetic model $\left(R^{2}>0.99\right)$ than the PFO kinetic model $\left(R^{2}>\right.$ 0.88) (Table 1). 
Table 1. Parameters for the Pseudo First and the Second Order of BACs on PAC $\left([B A C]_{0}=200 \mathrm{mg} \mathrm{L}^{-1} ; \mathrm{pH}=7.0\right.$; temperature $=25^{\circ} \mathrm{C}$; contact time $=120 \mathrm{~min} ;[\mathrm{PAC}]=1.2 \mathrm{~g} \mathrm{~L}^{-1}$ )

\begin{tabular}{|c|c|c|c|}
\hline Models & BACs & Parameters & $\mathbf{R}^{2}$ \\
\hline \multirow{3}{*}{$\begin{array}{l}\text { Pseudo-first } \\
\text { order }\end{array}$} & $\mathrm{BAC}_{12}$ & $\begin{aligned} \mathrm{q}_{\mathrm{e}} & =93.33 \mathrm{mg} \mathrm{g}^{-1} \\
\mathrm{k}_{1} & =0.0972 \mathrm{~min}^{-1}\end{aligned}$ & 0.956 \\
\hline & $\mathrm{BAC}_{14}$ & $\begin{aligned} \mathrm{q}_{\mathrm{e}} & =64.84 \mathrm{mg} \mathrm{g}^{-1} \\
\mathrm{k}_{1} & =0.0417 \mathrm{~min}^{-1}\end{aligned}$ & 0.880 \\
\hline & $\mathrm{BAC}_{16}$ & $\begin{aligned} \mathrm{q}_{\mathrm{e}} & =58.21 \mathrm{mg} \mathrm{g}^{-1} \\
\mathrm{k}_{1} & =0.0473 \mathrm{~min}^{-1}\end{aligned}$ & 0.911 \\
\hline \multirow{3}{*}{$\begin{array}{l}\text { Pseudo-second } \\
\text { order }\end{array}$} & $\mathrm{BAC}_{12}$ & $\begin{array}{c}\mathrm{q}_{\mathrm{e}}=147.06 \mathrm{mg} \mathrm{g}^{-1} \\
\mathrm{k}_{2}=0.00472 \mathrm{mg}^{-1} \mathrm{~min}^{-1}\end{array}$ & 0.999 \\
\hline & $\mathrm{BAC}_{14}$ & $\begin{aligned} \mathrm{q}_{\mathrm{e}}=158.73 \mathrm{mg} \mathrm{g}^{-1} \\
\mathrm{k}_{2}=0.00529 \mathrm{gmg}^{-1} \mathrm{~min}^{-1}\end{aligned}$ & 0.999 \\
\hline & $\mathrm{BAC}_{16}$ & $\begin{array}{c}\mathrm{q}_{\mathrm{e}}=161.29 \mathrm{mg} \mathrm{g}^{-1} \\
\mathrm{k}_{2}=0.00591 \mathrm{~g} \mathrm{mg}^{-1} \mathrm{~min}^{-1}\end{array}$ & 0.998 \\
\hline
\end{tabular}

\subsection{Adsorption Isotherms}

Adsorption isotherm experiments using $\mathrm{BAC}_{12}, \mathrm{BAC}_{14}$, and $\mathrm{BAC}_{16}$ were conducted in the concentration range of $200-450 \mathrm{mg} \mathrm{L}^{-1}$ using the same amount of PAC $\left(1.125 \mathrm{~g} \mathrm{~L}^{-1}\right)$ at $\mathrm{pH} 7$ and $25^{\circ} \mathrm{C}$. The equilibrium time was $120 \mathrm{~min}$. The calculated isotherm model parameters, namely $K_{L}, q_{\max }, K_{F}$, and $n$ values, and $R^{2}$ values are summarized in Table 2. The $R^{2}$ values for the Langmuir model were $>0.99$ and those for the Freundlich model ranged between 0.81 and 0.95 , indicating that the adsorption kinetics were better fitted to the Langmuir model. This result might be due to the homogenous distribution of active sites on the PAC surface [36]. In other studies, the Langmuir model was also suitable for the adsorption of BACs, and $q_{\max }$ varied according to the type of adsorbent used. When agricultural soil $\left(\mathrm{BAC}_{12}\right.$ : $6.3-35.7 \mathrm{mg} \mathrm{g}^{-1}$ and $\mathrm{BAC}_{14}$ : 8.8-38.9 $\mathrm{mg} \mathrm{g}^{-1}$ ) and sewage sludge $\left(\mathrm{BAC}_{12}: 67 \mathrm{mg} \mathrm{g}^{-1}\right.$ and $\mathrm{BAC}_{14}$ : $73 \mathrm{mg} \mathrm{g}^{-1}$ ) were used as adsorbents for BAC removal, however, the $q_{\max }$ values obtained soil and sludge were lower than those reported herein [37, 38]. This is because PAC has more active sites that can react with adsorbents compared to soil and sludge.

Table 2. Langmuir and Freundlich Model Parameters Obtained in This Study $\left(\mathrm{pH}=7.0 \pm 0.1\right.$, temperature $=25^{\circ} \mathrm{C}$, contact time $=120 \mathrm{~min},[\mathrm{PAC}]=1.2 \mathrm{~g} \mathrm{~L}^{-1}$ )

\begin{tabular}{|c|c|c|c|}
\hline Isotherm model & BAC & Parameters & $\mathbf{R}^{2}$ \\
\hline \multirow{3}{*}{ Langmuir } & $\mathrm{BAC}_{12}$ & $\begin{aligned} q_{\max } & =188.68 \mathrm{mg} \mathrm{g}^{-1} \\
K_{L} & =4.89 \mathrm{~L} \mathrm{mg}^{-1}\end{aligned}$ & 0.997 \\
\hline & $\mathrm{BAC}_{14}$ & $\begin{aligned} q_{\max } & =203.25 \mathrm{mg} \mathrm{g}^{-1} \\
K_{L} & =6.97 \mathrm{~L} \mathrm{mg}^{-1}\end{aligned}$ & 0.992 \\
\hline & $\mathrm{BAC}_{16}$ & $\begin{aligned} q_{\max } & =206.19 \mathrm{mg} \mathrm{g}^{-1} \\
K_{L} & =8.10 \mathrm{~L} \mathrm{mg}^{-1}\end{aligned}$ & 0.997 \\
\hline \multirow{3}{*}{ Freundlich } & $\mathrm{BAC}_{12}$ & $\begin{array}{c}n=21.41 \\
\left.K_{F}=144.84(\mathrm{mg} / \mathrm{g}) /(\mathrm{mg} / \mathrm{L})^{1 / \mathrm{n}}\right)\end{array}$ & 0.886 \\
\hline & $\mathrm{BAC}_{14}$ & $\begin{array}{c}n=6.77 \\
\left.K_{F}=119.84(\mathrm{mg} / \mathrm{g}) /(\mathrm{mg} / \mathrm{L})^{1 / \mathrm{n}}\right)\end{array}$ & 0.949 \\
\hline & $\mathrm{BAC}_{16}$ & $\begin{array}{c}n=15.33 \\
\left.K_{F}=139.35(\mathrm{mg} / \mathrm{g}) /(\mathrm{mg} / \mathrm{L})^{1 / \mathrm{n}}\right)\end{array}$ & 0.813 \\
\hline
\end{tabular}

Interestingly, parameters such as $K_{L}$ and $q_{\max }$ increased as the alkyl chain length increased. This result indicates that the amount of $\mathrm{BAC}_{16}$ adsorbed onto PAC was the highest, followed by the amounts of $\mathrm{BAC}_{14}$ and $\mathrm{BAC}_{12}$, implying that the effective adsorption process can occur as increasing the hydrophobicity of BAC molecules.

\subsection{Competitive Adsorption Kinetics}

In the water environment, more than two BACs can be simultaneously present in water $[14,18,39,40]$. Therefore, it is important to examine the competitive adsorption of BACs. We conducted binary $\left(\mathrm{BAC}_{12}\right.$ and $\mathrm{BAC}_{14}, \mathrm{BAC}_{12}$ and $\mathrm{BAC}_{16}$, and $\mathrm{BAC}_{14}$ and $\left.\mathrm{BAC}_{16}\right)$ and ternary $\left(\mathrm{BAC}_{12}, \mathrm{BAC}_{14}\right.$, and $\left.\mathrm{BAC}_{16}\right)$ adsorption experiments (Figs. 2(a) $-(d)$ ).

The binary adsorption results showed that that the adsorption removal rate of BACs with longer alkyl chains was higher than those of the BACs with shorter alkyl chains (Figs. 2(a)-(c)). For the binary adsorption of $\mathrm{BAC}_{12}$ and $\mathrm{BAC}_{14}$ by $\mathrm{PAC}$ for $120 \mathrm{~min}$, the adsorption capacities of $\mathrm{BAC}_{12}$ and $\mathrm{BAC}_{14}$ were $64.0 \%$ and 9.2\% lower than those achieved during the single adsorption of $\mathrm{BAC}_{12}$ (Fig. S1(a)) and $\mathrm{BAC}_{14}$ (Fig. S1(b)) by PAC, respectively. In addition, the binary experiment obtained using $\mathrm{BAC}_{12}$ and $\mathrm{BAC}_{16}$ revealed that the adsorption of $\mathrm{BAC}_{16}$ was more effective than that of $\mathrm{BAC}_{12}$; the adsorption capacities of $\mathrm{BAC}_{12}$ and $\mathrm{BAC}_{16}$ by PAC were 66.7 and $2.1 \%$ lower than those achieved during the single $\mathrm{BAC}_{12}$ (Fig. S1(c)) and single $\mathrm{BAC}_{16}$ (Fig. S1(d)) adsorption by $\mathrm{PAC}$, respectively. Moreover, the binary experiment obtained using $\mathrm{BAC}_{14}$ and $\mathrm{BAC}_{16}$ indicated that the adsorption capacities of $\mathrm{BAC}_{14}$ and $\mathrm{BAC}_{16}$ were 48.3 and $24.3 \%$ lower than those achieved during the single $\mathrm{BAC}_{14}$ (Fig. $\mathrm{S} 1(\mathrm{e})$ ) and single $\mathrm{BAC}_{16}$ adsorption by PAC (Fig. S1(f)), respectively. The differences in adsorption capacity are summarized in Table S3.

For ternary adsorption experiment using three BACs showed the similar result (Fig. 2(d)). Fig. 2(d) showed that the removal of $\mathrm{BAC}_{16}$ is the highest, followed by $\mathrm{BAC}_{14}$, and $\mathrm{BAC}_{12}$. Fig. S2 also showed the reduction of adsorption capacity of each BAC between single and ternary conditions. The adsorption capacity of each BAC in ternary condition decreased compared to single $\mathrm{BAC}$ condition. $\mathrm{BAC}_{12}$ had the largest adsorption capacity reduction (76.0\%), followed by $\mathrm{BAC}_{14}(52.0 \%)$, and $\mathrm{BAC}_{16}(30.5 \%)$ at equilibrium. This result indicated that the van der Waals forces between the high-molecular-weight BACs and PAC were stronger than those between the low-molecular-weight BACs and PAC. Ismail et al. [23] reported similar results for the simultaneous adsorption of dodecyl trimethyl ammonium chloride $\left(\mathrm{C}_{12} \mathrm{TMA}\right)$ and $\mathrm{BAC}_{16}$ using primary sludge; the adsorption capacity of $\mathrm{C}_{12} \mathrm{TMA}$ decreased up to $52.5 \%$. However, the adsorption capacity of $\mathrm{BAC}_{16}$, which has a longer alkyl chain length and higher molecular weight than $\mathrm{C}_{12}$ TMA, decreased slightly $(<4.3 \%)$.

\subsection{Effect of $\mathrm{pH}$}

Electrostatic interaction theory has been used to understand the adsorption of organic molecules, such as pharmaceuticals and personal care products by adsorbent [41, 42]. The electrostatic interaction between the adsorbent and contaminant can change upon changing the $\mathrm{pH}$. A previous study reported that BACs adsorption 

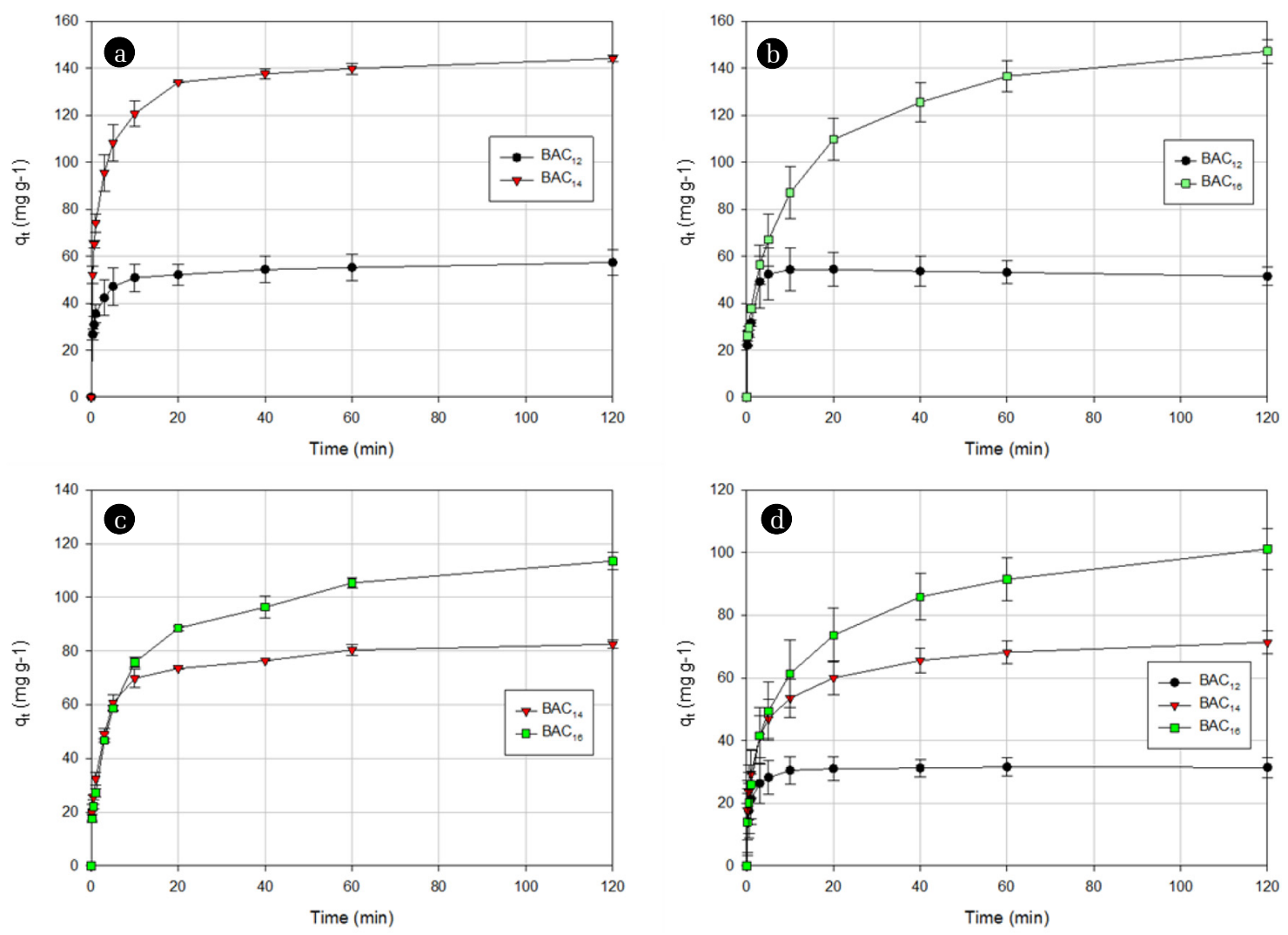

Fig. 2. Competitive adsorption of (a) $\mathrm{BAC}_{12}$ and $\mathrm{BAC}_{14}$, (b) $\mathrm{BAC}_{12}$ and $\mathrm{BAC}_{16}$, (c) $\mathrm{BAC}_{14}$ and $\mathrm{BAC}_{16}$, and (d) $\mathrm{BAC}_{12}, \mathrm{BAC}_{14}$ and $\mathrm{BAC}_{16}$ ([BAC]$]_{0}$ $=200 \mathrm{mg} \mathrm{L}^{-1}$, temperature $\left.=298 \mathrm{~K}, \mathrm{pH}=7.0 \pm 0.1,[\mathrm{PAC}]=1.2 \mathrm{~g} \mathrm{~L}^{-1}\right)$.

onto natural clays was controlled by ion exchange rather than van der Waals force at environmentally relevant concentration [39]. However, since BACs can be positively charged regardless of $\mathrm{pH}$ so that only the surface charge of PAC was changed with the $\mathrm{pH}$ [43] (Table S2). When the $\mathrm{pH}$ was lower than the $\mathrm{pH}_{\mathrm{pzc}}$ of PAC (6.48), PAC can be positively charged and when the $\mathrm{pH}$ was higher than the $\mathrm{pH}_{\mathrm{pzc}}$ of PAC, the adsorbent negatively charged. Therefore, electrostatic attraction between PAC surfaces and BACs can play an important role.

To investigate the effect of $\mathrm{pH}$ on the adsorption of BACs by $\mathrm{PAC}$, we varied the $\mathrm{pH}$ of the reaction solution in the range of 4-10 using the buffer systems. The effect of $\mathrm{pH}$ on the $q_{e}$ values of BACs is presented in Fig. 3, which illustrates that the $q_{e}$ values of the BACs increased with increasing $\mathrm{pH}$ from 4 to 7 and finally it reached a plateau. At $\mathrm{pH} 4$ and 5.5, which were lower than $\mathrm{pH}_{\mathrm{pzc}}$ of PAC, PAC is positively charged owing to the presence of $\mathrm{H}^{+}$ions, thus PAC repelled the positively charged BACs, resulting in lowering $q_{e}$ values. In contrast, at $\mathrm{pH} 7$ and 8.5, the surface of PAC was negatively charged and $q_{e}$ was higher than that of lower $\mathrm{pH}$ conditions due to the electrostatic interaction. Since PAC does not contain many functional groups prior to its chemical modification, we can assume that van der Waals interaction played a more important role in adsorption than chemical interactions.

Interestingly, while the $q_{e}$ values of $\mathrm{BAC}_{14}$ and $\mathrm{BAC}_{16}$ did not change significantly with the $\mathrm{pH}$, the change in $q_{e}$ of $\mathrm{BAC}_{12}$ was more significant upon changing the $\mathrm{pH}$ (Fig. 3). This result implied

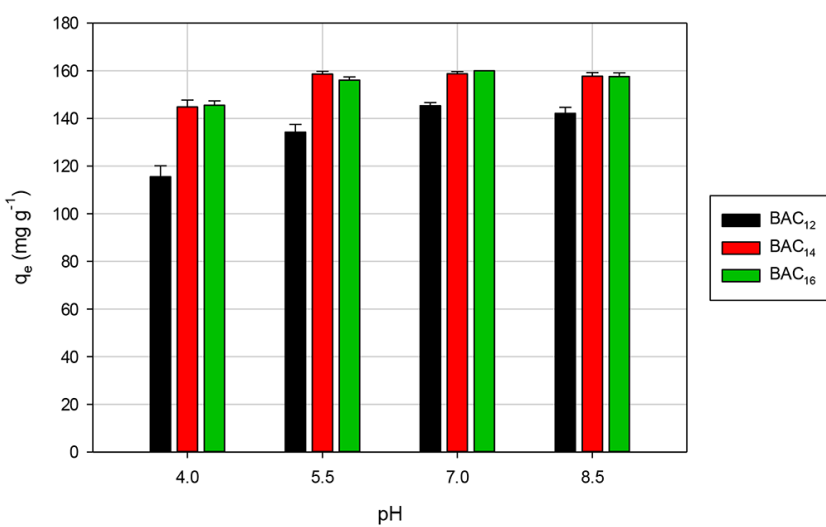

Fig. 3. Effect of the $\mathrm{pH}$ on the adsorption of benzalkonium chlorides (BACs) $\left([B A C]_{0}=200 \mathrm{mg} \mathrm{L}^{-1}\right.$, contact time $=120 \mathrm{~min}$, temperature $=25^{\circ} \mathrm{C},[\mathrm{PAC}]=1.2 \mathrm{~g} \mathrm{~L}^{-1}$ ). Here, $q_{\mathrm{e}}$ denotes adsorption capacity at the equilibrium.

that that, while the electrostatic interaction is an important adsorption mechanism for $\mathrm{BAC}_{12}$, van der Waals interaction and hydrophobicity can play more important roles during the adsorption of $\mathrm{BAC}_{14}$ and $\mathrm{BAC}_{16}$ onto PAC.

\subsection{Thermodynamic Analysis}

Temperature is an important factor that can affect adsorption 
kinetics. In this study, to investigate the temperature effect on the adsorption of BACs on PAC, adsorption experiments were performed at different temperatures $\left(277\left(4^{\circ} \mathrm{C}\right), 298\left(25^{\circ} \mathrm{C}\right)\right.$, and 308 $\left.\mathrm{K}\left(35^{\circ} \mathrm{C}\right)\right)$. Fig. 4 showed that, as the temperature increased from 277 to $308 \mathrm{~K}$, the $q_{\max }$ value of the BACs increased from 169.49 $192.31 \mathrm{mg} \mathrm{g}^{-1}$ to $232.56-264.62 \mathrm{mg} \mathrm{g}^{-1}$. This result indicates that the adsorption of BACs on PAC was endothermic, implying that, as the temperature increased, BAC can move more freely and effectively attached to the active surface sites of PAC.

The thermodynamic parameters such as standard enthalpy change $\left(\Delta H^{0} ; \mathrm{kJ} \mathrm{mol}^{-1}\right)$, standard entropy change $\left(\Delta S^{0} ; \mathrm{J} \mathrm{mol}^{-1} \mathrm{~K}^{-}\right.$ ${ }^{1}$ ), and the resulting the standard Gibbs free energy change $\left(\Delta G^{0} ; \mathrm{kJ} \mathrm{mol}^{-1}\right)$, can be calculated using the temperature dependence of Langmuir equilibrium coefficient, as shown in Eq. (8) to $(10)$.

$$
\begin{gathered}
\Delta G^{0}=-R T \ln \left(K_{L}\right) \\
\Delta G^{0}=\Delta H^{0}-T \Delta S^{0} \\
\ln \left(K_{L}\right)=\frac{\Delta S^{0}}{R}-\frac{\Delta H^{0}}{R T},
\end{gathered}
$$

where $R$ is the universal gas constant $\left(8.314 \mathrm{~J} \mathrm{~mol}^{-1} \mathrm{~K}^{-1}\right), T$ is the temperature $(\mathrm{K})$, and $K_{L}$ is the Langmuir equilibrium coefficient $\left(\mathrm{L} \mathrm{mol}{ }^{-1}\right.$ ). $\Delta G^{0}$ was obtained using the experimental $K_{L}$ value. $\Delta S^{0}$ and $\Delta H^{0}$ were determined using the slope and y-intercept of the linear regression of $\ln \left(K_{L}\right)$ vs. $1 / T$, respectively. The calculated values of the thermodynamic parameters are summarized in Table 3. The negative values of $\Delta G^{0}$ indicated that all adsorption reactions occur spontaneously. When the temperature increased from 277 to $308 \mathrm{~K}, \Delta G^{0}$ was decreased significantly, indicating that the reaction proceeds more spontaneously at higher temperatures.

In gas adsorption systems, $\Delta H^{0}$ is usually negative (exothermic reaction). However, in liquid adsorption systems, $\Delta H^{0}$ can be either negative or positive [44]. The positive values of $\Delta H^{0}$ in this study indicate that the adsorption of BACs by PAC was endothermic. Furthermore, the $\Delta H^{0}$ values of the BACs obtained in this study (1.000-3.571 $\mathrm{kJ} \mathrm{mol}^{-1}$ ) indicated that adsorption is governed by physisorption, such as van der Waals forces (i.e., $\sim 20 \mathrm{~kJ} \mathrm{~mol}^{-1}$ ), and not chemisorption (i.e., $80-200 \mathrm{~kJ} \mathrm{~mol}^{-1}$ ) [25].

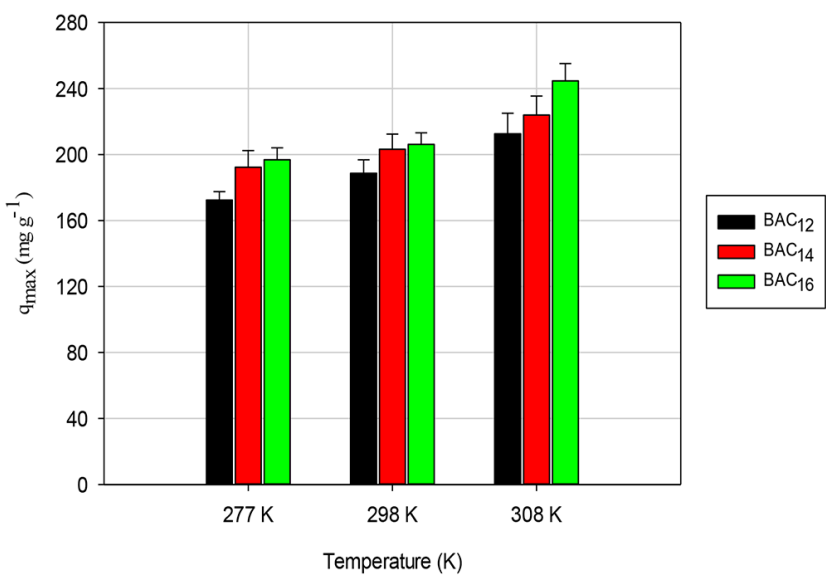

Fig. 4. Effect of the temperature on the adsorption of benzalkonium chlorides $(\mathrm{BACs})\left([\mathrm{BAC}]_{0}=200 \mathrm{mg} \mathrm{L}^{-1} ;[\mathrm{PAC}]=1.2 \mathrm{~g} \mathrm{~L}^{-1}\right.$; $\mathrm{pH}=7.0$; contact time $=180 \mathrm{~min}$ ).

Next, positive values of $\Delta S^{0}$ obtained in this study imply that the increasing randomness at the solid-liquid interface during the adsorption of BACs on PAC [45]. When BACs are added to water, water molecules surround the BACs and form ordered structures. However, when BACs are adsorbed onto PAC, the water molecules surrounding the BACs are detached and their degree of freedom increases [46]. Another reason for the increased randomness is that the PAC surface becomes more congested because large molecules are adsorbed on its surface [48]; $\mathrm{BAC}_{12}, \mathrm{BAC}_{14}$, and $\mathrm{BAC}_{16}$ have similar tendencies. These results imply that $\Delta S^{0}$ would increase when large molecules, such as BACs, are adsorbed on PAC. It is also reported that the removal reactions of heavy metals, dyes, and micropollutants using PAC were endothermic and presented positive $\Delta S^{0}$ values [47-49].

\subsection{Detoxification of BACs}

Finally, to assess the detoxification of the treated solution after the adsorption process, we conducted acute toxicity tests using a Microtox test. While $200 \mathrm{mg} \mathrm{L}^{-1}$ of BACs were almost completely adsorbed by $1.2 \mathrm{~g} \mathrm{~L}^{-1}$ of PAC (<98\%) within $120 \mathrm{~min}$, up to $69 \%$ of detoxification was achieved after the adsorption reaction (Fig. S3). One-way of analysis variance (ANOVA) have conducted by

\begin{tabular}{|c|c|c|c|c|}
\hline BACs & temperature (K) & $\left.\Delta G^{0}(\mathrm{~kJ} \mathrm{~mol})^{-1}\right)$ & $\Delta H^{0}\left(\mathrm{~kJ} \mathrm{\textrm {mol } ^ { - 1 } )}\right.$ & $\Delta S^{0}\left(\mathrm{Jol}^{-1} \mathrm{~K}^{-1}\right)$ \\
\hline \multirow{3}{*}{$\mathrm{BAC}_{12}$} & 277 & -3.576 & & \\
\hline & 298 & -3.931 & 1.000 & 16.525 \\
\hline & 308 & -4.085 & & \\
\hline \multirow{3}{*}{$\mathrm{BAC}_{14}$} & 277 & -4.276 & & \\
\hline & 298 & -4.811 & 3.497 & 28.020 \\
\hline & 308 & -5.164 & & \\
\hline \multirow{3}{*}{$\mathrm{BAC}_{16}$} & 277 & -4.679 & & \\
\hline & 298 & -5.184 & 3.571 & 29.689 \\
\hline & 308 & -5.641 & & \\
\hline
\end{tabular}

Table 3. Thermodynamic Parameters of the BACs in This Study $\left(\Delta C^{0}, \Delta H^{0}\right.$, and $\Delta S^{0}$ denote the standard Gibbs free energy, enthalpy, and entropy changes, respectively) 


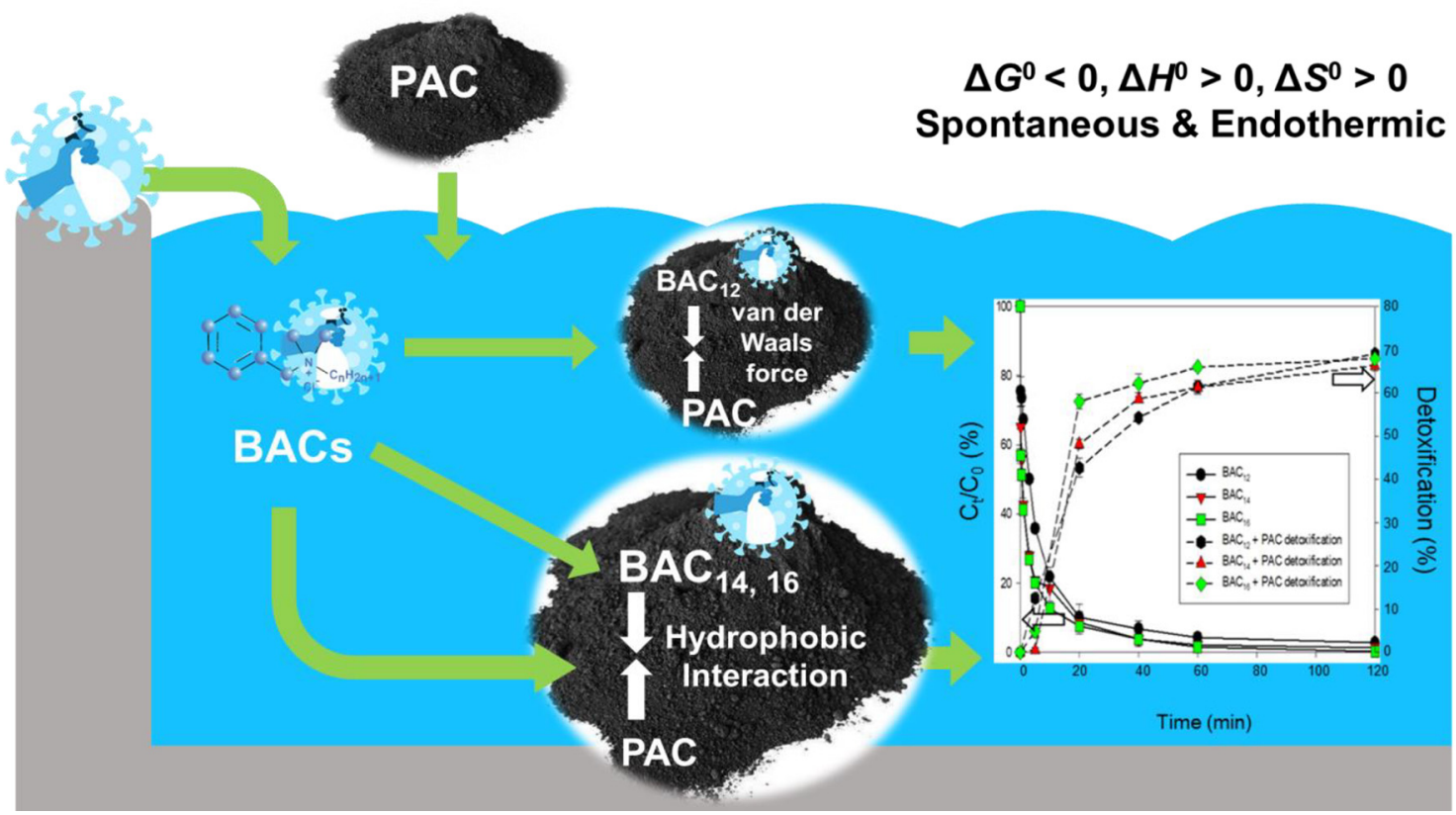

Fig. 5. BAC adsorption mechanism by PAC.

using R program (R Core Team, Vienna, Austria) to compare the toxicity responses before and after the BACs adsorption onto PAC. We observed statistical significance before and after the adsorption $(\mathrm{p}<0.05)$. Even though the remaining concentration of $\mathrm{BAC}_{12}$, $\mathrm{BAC}_{14}$, and $\mathrm{BAC}_{16}$ in the treated solutions were 2.2, 1.4, and 0.2 $\mathrm{mg} \mathrm{L}^{-1}$, we observed remaining toxicity for $V$. fischeri. The reported 5 min $\mathrm{EC}_{50}$ values of $V$. fischeri for $\mathrm{BAC}_{12}, \mathrm{BAC}_{14}$, and $\mathrm{BAC}_{16}$ were $0.19,0.38$, and $0.92 \mathrm{mg} \mathrm{L}^{-1}$, respectively [4]. This result implies that, if we treat high concentrations of BACs in water, additional treatment or dilution strategy to reduce the BAC level is required to reduce the remaining acute toxicity.

The BAC adsorption mechanism by PAC was summarized in Fig. 5. The adsorption mechanism of BACs can be explained by physisorption mediated with van der Waals forces and hydrophobic interactions, and by the endothermic and spontaneous reactions, along with the reduction of the toxicity.

\section{Conclusions}

Kinetic studies revealed that high concentration of BACs was effectively adsorbed onto PAC and the PSO kinetic reaction model was more suitable to describe the adsorption process. Competitive BAC adsorption indicated that BACs with longer alkyl chains showed higher adsorption removal than BACs with shorter alkyl chains. The adsorption equilibrium results suggested that the adsorption of BACs on PAC fitted the Langmuir model $\left(R^{2}>0.99\right)$ better than the Freundlich model. The effect of $\mathrm{pH}$ was assessed, and the optimum adsorption $\mathrm{pH}$ was determined to be 7 . The thermodynamic analysis demonstrated that the adsorption of BACs on PAC was spontaneous and endothermic. The adsorption reaction was governed by physisorption owing to the low $\Delta H^{0}$ value $(<$
$20 \mathrm{~kJ} \mathrm{~mol}^{-1}$ ). Since $\Delta \mathrm{H}_{0}$ and $\Delta \mathrm{S}_{0}$ were positive, the adsorption was an endothermic reaction. Finally, we observed $70 \%$ of BACs detoxification in the presence of PAC using $V$. fishceri.

In this study, we obtained the insight in which the adsorption process with PAC can be an effective option for treating BACs with the reduction of toxicity in real wastewater treatment facilities especially even high concentration levels. However, further study for process optimization is required to apply our findings with real wastewater containing BACs.

\section{Acknowledgments}

This study was supported by the Korea Environment Industry \& Technology Institute (KEITI) through the project for developing innovative drinking water and wastewater technologies funded by Korea Ministry of Environment (MOE) (NO. 2019002710006).

\section{Author Contributions}

T.K.K. (postdoctor) conducted the experiments and wrote the manuscript. W.S.C. (master graduate) conducted the adsorption experiments. T.Y.K. (Ph.D. student) conducted the adsorption experiments. S.H.C. (Researcher) concepted and supervised the adsorption experiments. Y.S.H. (Researcher) concepted, supervised the toxicity experiments. K.D.Z. (Professor) concepted, supervised, wrote and revised the manuscript.

\section{References}

1. Pereira BMP, Tagkopoulos I. Benzalkonium chlorides: uses, 
regulatory status, and microbial resistance. Appl. Environ. Microbiol. 2019;85(13):e00377-19.

2. Hora, PI, Pati SG, McNamara PJ, Arnold WA. Increased use of quaternary ammonium compounds during the SARS-CoV-2 pandemic and beyond: consideration of environmental implications. Environ. Sci. Technol. Lett. 2020;7(9):622-631.

3. Zanini GP, Ovesen RG, Hansen HCB, Strobel BW. Adsorption of the disinfectant benzalkonium chloride on montmorillonite. Synergistic effect in mixture of molecules with different chain lengths. J. Environ. Manage. 2013;128:100-105.

4. Tezel U, Giles H, deRussy A, Pavlostathis SG. Effect of Counter Ions and Natural Organic Matter on the Toxicity of Benzalkonium Chloride. Proc. Water Environ. Fed. 2009;2009 (17):621-631.

5. McNamara PJ, Levy SB. Triclosan: an instructive tale. Antimicrob. Agents Chemother. 2016;60(12):7015-7016.

6. Department of Health and Human services; Food and Drug Administration. Safety and effectiveness of health care antiseptics; topical antimicrobial drug products for over-the-counter human use. Federal Register 2017;82(242):60474-60503.

7. Ogilvie BH, Solis-Leal A, Lopez JB, Poole BD, Robison RA, Berges BK. Alcohol-free hand sanitizer and other quaternary ammonium disinfectants quickly and effectively inactivate SARS-CoV-2. J. Hosp. Infect. 2021;108:142-145.

8. Robinson AJ, Foster RS, Halbert AR, King E, Orchard D. Granular parakeratosis induced by benzalkonium chloride exposure from laundry rinse aids. Aust. J. Dermatol. 2017;58(3):e138-e140.

9. Kampf G. Potential role of inanimate surfaces for the spread of coronaviruses and their inactivation with disinfectant agents. Infect. Prev. in Prac. 2020;2(2):100044.

10. Barber OW, Hartmann EM. Benzalkonium chloride:A systematic review of its environmental entry through wastewater treatment, potential impact, and mitigation strategies. Crit. Rev. Environ. Sci. Technol. 2021:1-30.

11. Kümmerer K, Eitel A, Braun U, et al. Analysis of benzalkonium chloride in the effluent from European hospitals by solid-phase extraction and high-performance liquid chromatography with post-column ion-pairing and fluorescence detection. J. Chromatogr. A 1997;774(1-2):281-286.

12. Kreuzinger N, Fuerhacker M, Scharf S, Uhl M, Gans O, Grillitsch B. Methodological approach towards the environmental significance of uncharacterized substances - quaternary ammonium compounds as an example. Desalination 2007;215(1-3): 209-222.

13. Martínez-Carballo E, Sitka A, González-Barreiro C, et al. Determination of selected quaternary ammonium compounds by liquid chromatography with mass spectrometry. Part I. Application to surface, waste and indirect discharge water samples in Austria. Environ. Pollut. 2007;145(2):489-496.

14. Reynolds L, Blok J, De Morsier A, Gerike P, Wellens H, Bontinck W. Evaluation of the toxicity of substances to be assessed for biodegradability. Chemosphere 1987;16(10-12):2259-2277.

15. Yang J, Tezel U, Li K, Pavlostathis SG. Prolonged exposure of mixed aerobic cultures to low temperature and benzalkonium chloride affect the rate and extent of nitrification. Bioresour. Technol. 2015;179:193-201.

16. Sreevidya VS, Lenz KA, Svoboda KR, Ma H. Benzalkonium chloride, benzethonium chloride, and chloroxylenol-Three replacement antimicrobials are more toxic than triclosan and triclocarban in two model organisms. Environ. Pollut. 2018;235: 814-824.

17. Kim S, Ji K, Shin H, et al. Occurrences of benzalkonium chloride in streams near a pharmaceutical manufacturing complex in Korea and associated ecological risk. Chemosphere 2020;256: 127084.

18. Zhang Q, Xia YF, Hong JM. Mechanism and toxicity research of benzalkonium chloride oxidation in aqueous solution by $\mathrm{H}_{2} \mathrm{O}_{2} / \mathrm{Fe}^{2+}$ process. Environ. Sci. Pollut. Res. 2016;23(17):17822-17830.

19. Huang N, Wang T, Wang WL, Wu QY, Li A, Hu HY. UV/chlorine as an advanced oxidation process for the degradation of benzalkonium chloride:synergistic effect, transformation products and toxicity evaluation. Water Res. 2017;114:246-253.

20. Khan AH, Kim J, Sumarah M, Macfie SM, Ray MB. Toxicity reduction and improved biodegradability of benzalkonium chlorides by ozone/hydrogen peroxide advanced oxidation process. Sep. Purif. Technol. 2017;185:72-82.

21. Huang N, Wang WL, Xu ZB, Lee MY, Wu QY, Hu HY. A study of synergistic oxidation between ozone and chlorine on benzalkonium chloride degradation:Reactive species and degradation pathway. Chem. Eng. J. 2020;382:122856.

22. Ismail ZZ, Tezel U, Pavlostathis SG. Sorption of quaternary ammonium compounds to municipal sludge. Water Res. 2010;44(7):2303-2313.

23. Farías T, De Menorval LC, Zajac J, Rivera A. Benzalkonium chloride and sulfamethoxazole adsorption onto natural clinoptilolite:Effect of time, ionic strength, $\mathrm{pH}$ and temperature. $J$. Colloid. Interface. Sci. 2011;363(2):465-475.

24. Ong L, Soetaredjo F, Kurniawan A, Ayucitra A, Liu JC, Ismadji $\mathrm{S}$. Investigation on the montmorillonite adsorption of biocidal compounds incorporating thermodynamical-based multicomponent adsorption isotherm. Chem. Eng. J. 2014;241:9-18.

25. Ndabambi M, Kwon JH. Benzalkonium ion sorption to peat and clays:Relative contributions of ion exchange and van der Waals interactions. Chemosphere 2020;247:125924.

26. Georgiev GA, Yokoi N, Koev K, et al. Surface chemistry study of the interactions of benzalkonium chloride with films of meibum, corneal cells lipids, and whole tears. Investig. Ophthalmol. Vis. Sci. 2011;52(7):4645-4654.

27. Kampf G. Potential role of inanimate surfaces for the spread of coronaviruses and their inactivation with disinfectant agents. Infect. Prev. Prac. 2020;2(2):100044.

28. Robinson AJ, Foster RS, Halbert AR, King E, Orchard D. Granular parakeratosis induced by benzalkonium chloride exposure from laundry rinse aids. Aust. J. Dermatol. 2017;58(3):e138-e140.

29. Dada A, Olalekan A, Olatunya A, Dada O. Langmuir Freundlich Temkin, and Dubinin-Radushkevich isotherms studies of equilibrium sorption of $\mathrm{Zn}^{2+}$ unto phosphoric acid modified rice husk. IOSR J. Appl. Chem. 2012;3(1):38-45.

30. Fu J, Chen Z, Wang M, et al. Adsorption of methylene blue by a high-efficiency adsorbent (polydopamine microspheres):kinetics, isotherm, thermodynamics and mechanism analysis. Chem. Eng. J. 2015;259:53-61.

31. Allen S, Mckay G, Porter JF. Adsorption isotherm models for basic dye adsorption by peat in single and binary component 
systems. J. Colloid. Interface. Sci. 2004;280(2):322-333.

32. Grabińska-Sota E. Genotoxicity and biodegradation of quaternary ammonium salts in aquatic environments. J. Hazard. Mater. 2011;195:182-187.

33. Ho Y, McKay G. A comparison of chemisorption kinetic models applied to pollutant removal on various sorbents. Process Saf. Environ. Prot. 1998;76(4):332-340.

34. Rengaraj S, Kim Y, Joo CK, Yi J. Removal of copper from aqueous solution by aminated and protonated mesoporous aluminas:kinetics and equilibrium. J. Colloid. Interface Sci. 2004;273(1): 14-21.

35. Pandian AMK, Karthikeyan C, Rajasimman M. Isotherm and kinetic studies on adsorption of malachite green using chemically synthesized silver nanoparticles. Nanotechnol. Environ. Eng. 2017;2(1):2.

36. Teresa García M, Campos E, Sánchez-Leal J, Comelles F. Sorption of alkyl benzyl dimethyl ammonium compounds by activated sludge. J. Dispers. Sci. Technol. 2006;27(5):739-744.

37. Khan AH, Macfie SM, Ray MB. Sorption and leaching of benzalkonium chlorides in agricultural soils. J. Environ. Manage. 2017;196:26-35.

38. Ferrer I, Furlong ET. Identification of alkyl dimethylbenzylammonium surfactants in water samples by solid-phase extraction followed by ion trap LC/MS and LC/MS/MS. Environ. Sci. Technol. 2001;35(12):2583-2588.

39. Zhang C, Cui F, Zeng GM, et al. Quaternary ammonium compounds (QACs):a review on occurrence, fate and toxicity in the environment. Sci. Total Environ. 2015;518:352-362.

40. Hasan Z, Jeon J, Jhung SH. Adsorptive removal of naproxen and clofibric acid from water using metal-organic frameworks. J. Hazard. Mater. 2012;209:151-157.
41. Sarker M, Bhadra BN, Seo PW, Jhung SH. Adsorption of benzotriazole and benzimidazole from water over a Co-based metal azolate framework MAF-5 (Co). J. Hazard. Mater. 2017;324:131-138.

42. Ndabambi M, Kwon JH. Benzalkonium ion sorption to peat and clays:Relative contributions of ion exchange and van der Waals interactions. Chemosphere 2020;247:125924.

43. Lowell S, Shields JE, Thomas MA, Thommes M. Characterization of porous solids and powders: surface area, pore size and density. Dordrecht: Springer; 2012.

44. Boujelben N, Bouzid J, Elouear Z. Adsorption of nickel and copper onto natural iron oxide-coated sand from aqueous solutions:study in single and binary systems. J. Hazard. Mater. 2009;163(1):376-382

45. Alkan M, Demirbaş Ö., Çelikçapa S, Doğan M. Sorption of acid red 57 from aqueous solution onto sepiolite. J. Hazard. Mater. 2004;116(1-2):135-145.

46. Bhattacharyya KG, Sharma A. Kinetics and thermodynamics of methylene blue adsorption on neem (Azadirachta indica) leaf powder. Dyes Pigm. 2005;65(1):51-59.

47. Rao R, Ikram S, Ahmad J. Adsorption of $\mathrm{Pb}$ (II) on a composite material prepared from polystyrene-alumina and activated carbon:Kinetic and thermodynamic studies. J. Iran. Chem. Soc. 2011;8(4):931-943.

48. Suriyanon N, Punyapalakul P, Ngamcharussrivichai C. Mechanistic study of diclofenac and carbamazepine adsorption on functionalized silica-based porous materials. Chem. Eng. J. 2013;214:208-218.

49. Liu Y, Luo X, Zhang Z, Zhou P, Yang Z. Modeling and thermodynamics of methylene blue and acid blue 80 adsorption onto potato residue based activated carbon. Chem. Res. Chinese $U$. 2015;31(4):627-632. 